\title{
Role of peptide hormones in insect gut physiology
}

Rania Abou El Asrar ${ }^{\mathrm{a}, \mathrm{b}}$, Dorien Cools ${ }^{\mathrm{a}, \mathrm{b}}$ and Jozef Vanden Broeck ${ }^{\mathrm{a}}$

a Department of Biology, Research group of Molecular Developmental Physiology and Signal Transduction, Naamsestraat 59 box 2465, 3000 Leuven, Belgium

$\mathrm{b}$ equal contribution authorship

Rania Abou El Asrar (rania.abuelasrar@kuleuven.be)

Dorien Cools (dorien.cools@kuleuven.be)

Corresponding author:

Prof. Dr. Jozef Vanden Broeck (jozef.vandenbroeck@kuleuven.be) 


\title{
Highlights
}

Gut physiology is regulated by a complex interplay between neuropeptides.

The gut is innervated by the central and stomatogastric nervous systems.

Biostable neuropeptide mimetics can be a promising approach for pest management

\begin{abstract}
Nutrient uptake and digestion are essential for optimal growth and development. In insects, these processes are regulated by the gut-brain axis, which is a neurohumoral communication system for maintaining gut homeostasis. The insect gut is a complex organ consisting of three distinct structures, denominated foregut, midgut and hindgut, each with their specific specializations. These specializations are tightly regulated by the interplay of several neuropeptides: a versatile group of signalling molecules involved in a multitude of processes including gut physiology. Neuropeptides take part in the regulation of gut processes ranging from digestive enzyme release to muscle activity and satiety. Some neuropeptide mimetics are a promising strategy for ecological pest management. This review focuses on a selection of neuropeptides that are well-known for their role in gut physiology, and neuropeptides for which their mode of action is yet to be unravelled.
\end{abstract}

\section{Introduction}

Physiological, developmental and behavioural events in insects are coordinated by an interplay of multiple signalling molecules. An important class of these are small proteins (generally about 5-80 amino acid residues) known as neuropeptides, which are released from neurons, neurosecretory cells (NSC) or (entero)endocrine cells. Thus, neuropeptides can behave as circulating (endocrine) or local hormones (paracrine), as neuromodulators, or as co-transmitters. Most neuropeptides are pleiotropic, since they often display multiple biological activities and generate regulatory effects in a variety of processes. Neuropeptides are derived from larger, inactive precursors that undergo post-translational cleavage and further modifications (carboxy terminus amidation, sulfation of tyrosyl groups, disulphide bridge formation, etc.) during transport from the endoplasmic reticulum-Golgi network to their release sites enclosed in secretory granules [1,2]. Their action on target sites usually involves the activation of a class of membrane receptors known as G-protein coupled receptors (GPCRs). These initiate a cascade of intracellular events involving phospholipase $\mathrm{C}$ or adenylyl cyclase pathways, thus regulating the levels of second messengers, such as cyclic adenosine monophosphate (cAMP), diacylglycerol and inositol 1,4,5-trisphosphate [3].

Feeding behaviour is associated with three main physiological processes: (1) the perception and recognition of food, (2) endogenous nutritional and metabolic state, and (3) mechanical 
and digestive activities within the alimentary canal (gut). The latter include food intake, gut peristalsis, digestive enzyme release, nutrient absorption and excretion. In this review, a selection of some of the important peptides (Figure 1) that are involved in regulating gut activities is discussed.

\section{The enteric nervous system}

The insect gut is a complex organ differentiated into three distinct structures, each with their corresponding specializations. The foregut consists of the pharynx and esophagus that open into the crop, and the proventriculus. Food stored in the crop undergoes initial digestion by salivary gland enzymes and enzymes regurgitated from the midgut. The midgut's main function is secretion of digestive enzymes and nutrient absorption. The hindgut consists of the pylorus, the ileum and the rectum; its general function is osmotic regulation of internal fluids, excretion and faeces formation [4]. The Enteric Nervous System consists (ENS) of interconnected ganglia and nerve plexuses that innervate the alimentary tract and regulate gut motility [5] (Figure 2).

\section{Neuropeptides regulating gut physiology}

\section{Allatoregulatory peptides}

Insects have three structurally unrelated allatostatins (ASTs) (A-, B- and C- type) and two allatotropins (ATs) (Table 1). The first allatoregulatory peptides were isolated based on their effect on juvenile hormone synthesis in the corpora allata [6-8]: allatostatin is inhibitory and allatotropin is stimulatory. Since then, a plethora of functions have been attributed to these peptides including heart rhythmicity [9], circulatory system regulation [10] and a role in sleep [11] and photic entrainment of the circadian clock [12] (reviewed by Verlinden et al.[13]). The role of these peptides in feeding is supported by several studies. In the cockroach Blatella germanica, expression of AST-A in the midgut declined around the middle of the gonadotrophic cycle at the same period when food consumption increases to maximum. [14]. Starvation of Spodoptera littoralis larvae decreased the number of AST-A expressing enteroendocrine cells in the midgut, which rose again after refeeding [15].

Immunolocalization studies detected the presence of allatoregulatory peptides in the stomatogastric nervous system (SNS) (Figure 2) of multiple insect species [16-19]. Immunoreactivity for AST was also present in the nerves extending to the anterior midgut, ileum and rectum of Locusta migratoria [19]. In Lepidopterans [20-22], it was demonstrated that AST and AT are co-localized in the frontal ganglion, recurrent nerve and branching extending to the crop, stomodeal valve and some parts of the midgut. In Lacanobia oleracea, dual localization of AST-A and AST-C was observed.

Since their discovery, these peptides have been shown to control movement of food by excitatory and inhibitory mechanisms on the gut. ASTs inhibit foregut [23], midgut [24], and hindgut $[14,25]$ peristalsis, which can possibly suppress feeding, as was demonstrated by in vivo studies. When administered into the moth L. oleracea and the aphid Myzus persicae, 
Manduca sexta-AST (Manse-AST, Table 1) significantly reduced feeding, with a detrimental effect on weight gain and survival $[26,27]$. A similar effect was seen with $B$. germanica AST-A [14]. In Drosophila melanogaster, activation of AST-A neurons inhibited starvationinduced feeding [28]. Interestingly, the opposite effect on feeding was not observed in Ast-A null mutant flies [11]. Controlled thermogeneic activation of AST expression indicated that the neurons in the posterior lateral protocerebrum and the enteroendocrine cells are sufficient to suppress feeding [11]. The effect of ASTs on feeding has led investigators to develop neuropeptide analogues for use as pest control agents [29, 30]

The function of ATs usually is opposite of ASTs. They are generally myostimulatory peptides [17]. In hematophagous insects, such as Triatoma infestans, an AT-like peptide released from the Malpighian tubules stimulates hindgut contractions to facilitate the mixing of urine and faeces during post-prandial diuresis [31,32]. In agreement with the role of gut motility on feeding regulation, injection of Manse AT (Table 1) into L. oleracea or $S$. littoralis did not affect feeding or development [33]. Surprisingly, the reverse effect was observed in the Lepidopteran Bombyx mori [34]; AT inhibited spontaneous contractions in the pharynx, esophagus and ileum in both fed and starved larvae and prolonged latency to feeding. In vivo studies with Spodoptera frugiperda produced similar results; Manse-AT was associated with weight decrease and higher mortality whereas Manse-AST had no considerable effect on larval development [35]. The effect of allatoregulatory peptides on gut motility in this Lepidopteran insect was demonstrated in a later study [36]. S. frugiperda AST (AST-A) inhibited ileum contractions while Manse-AT stimulated them.

Allatoregulatory peptides may also control the release of digestive enzymes in response to food. AST-A increased the levels of amylase and protease activities in the midgut of $S$. littoralis [15], while in S. frugiperda, AST-A reduced the midgut levels of amylase and trypsin [36]. In the latter insect species, Manse-AT significantly increased the levels of amylase and trypsin.

\section{Kinins}

Kinins are pleiotropic factors acting at multiple levels of food intake and processing, diuresis and release of digestive enzymes. They are characterized by the FxxWG C-terminal sequence (Table 1). Kinins were first isolated from the Madeira cockroach Leucophaea maderae, as myotropic peptides acting on the hindgut [37]. Later, they were identified in other insects, either expressing a single kinin peptide or multiple kinin isoforms, encoded by a single precursor [38-40]. Kinins are expressed in the CNS and throughout the alimentary canal where they stimulate muscle contractions. Immunohistochemical and radioimmunoassay (RIA) techniques demonstrated that, in the blood-feeding bug Rhodnius prolixus, kinins are co-expressed with corticotropin-releasing factor-related diuretic hormones $(\mathrm{CRF} / \mathrm{DH})$ in the posterior lateral neurosecretory cells of the mesothoracic ganglionic mass and in neurohemal areas on abdominal nerves, suggesting the possibility of co-release of the peptides into the haemolymph [41].

In search of eco-friendly insecticides for pest control, kinins have been considered possible candidates. Kinin analogues cause detrimental effects when delivered to various insects; inhibition of larval weight gain was observed for the corn earworm, Helicoverpa zea [42, 43], 
and higher diuretic activity was measured in the housefly Musca domestica [42], both resulting in high mortality rates. More recently, tests with analogues in the blood-gorging $R$. prolixus demonstrated that the presence of biostable kinin analogues in the haemolymph resulted in smaller blood meals and slower diuresis rate, leading to reduction in urine excretion and an inability to moult $[44,45]$. This anti-feedant activity together with a reduction in honeydew production was also observed for the pea aphid Acyrthosiphon pisum [46].

\section{CRF-related diuretic hormone}

Corticotropin-releasing factor (CRF)-related diuretic hormones (DH) (example of structure is presented in Table 1) are named after their diuretic function (as reviewed by Gäde [47]). A correlation between CRF/DH release and feeding behaviour was first demonstrated in $M$. sexta, where high doses of $\mathrm{CRF} / \mathrm{DH}$-injections in larvae resulted in weight loss and decreased food consumption [48]. Likewise, it was shown that CRF/DH titers in the hemolymph of starved L. migratoria gradually rose after feeding, initiating post-feeding diuresis [49, 50]. Stretch receptors in the foregut may detect the presence of food, inducing a signal to release diuretic hormones. L. migratoria nymphs showed increased latency to the first meal upon injection of $\mathrm{CRF} / \mathrm{DH}$ analogues as well as a decrease in meal duration suggesting that CRFrelated diuretic hormones play a role in satiety [51]. These findings were later confirmed in Schistocerca gregaria by knockdown of CRF/DH through RNA interference, which resulted in increased food uptake. A rescue of this RNAi-induced knockdown by administering $\mathrm{CRF} / \mathrm{DH}$ resulted in reduced food consumption [52]. Recently, immunohistochemical assays in the CNS of the blood-gorging insect $R$. prolixus demonstrated diminished CRF-like staining in NSC following feeding and partial restocking in the period after the meal [53].These data were supported by temporal qPCR analysis of the CNS. Elevated haemolymph $\mathrm{CRF} / \mathrm{DH}$ titres prior to feeding resulted in lower blood meal consumption, while seemingly having no effect on the rate of postprandial diuresis [53]. Rhopr-CRF/DHreceptor transcripts are expressed in the CNS and throughout the gut, mainly the foregut, suggesting that CRF/DH maybe involved in muscle contraction in the gut [54]. Myotropic activity was already proposed for the cricket Acheta domesticus, where CRF/DH increases the frequency and amplitude of contractions of the foregut [55]. Muscle contractions in the hindgut might be related to expulsion of urine produced by the Malpighian tubules [56].

\section{Proctolin}

Proctolin is a potent myotropic with activity on visceral, skeletal and cardiac muscles. It is involved in a variety of processes including egg-laying [57] sexual behaviour [58], hemolymph circulation [59] and heart rhythmicity [9]. It was originally isolated and sequenced (Table 1) based on its myotropic activity on the hindgut of Periplanta americana $[60,61]$. Proctolin might be unique to invertebrates [62-64], with no homologs in vertebrates. Genomic search for proctolin precursor showed that it is absent in many insect species [65, 66] and there is no compelling evidence for presence of proctolin signalling in Lepidopterans [67-70]. An analogue of proctolin (Table 1) was also isolated from the brain of the Colorado potato beetle $[71,72]$. 
In L. migratoria, proctolin is present in all ganglia of the SNS, including the frontal ganglion, which supports its role in regulation of feeding and gut motility [73]. Proctolin immunoreactivity also reveals its presence in the thoracico-abdominal ganglion of the adult blow fly Calliphora erythrocephala [74] and the $8^{\text {th }}$ abdominal ganglion of L. migratoria [73], from which neurons extend to innervate the hindgut musculature. No proctolin immunoreactivity was observed in enteroendocrine (EE) cells of L. migratoria.

Much of the research on proctolin has focused on its effect on muscle contraction. In addition to the cockroach hindgut [61], proctolin stimulated contraction in the foregut of $S$. gregaria $[75,76]$ and L. migratoria, the midgut of L. migratoria [77] and R. prolixus [78], the pyloric sphincter in D. melanogaster [24], and the hindgut of Leucophaea maderae [79] and Nicrophorus vespilloides [55]. Therefore, it is regarded as a major neuromuscular modulator in the gut of insects. Injection of proctolin into B. germanica adults was not associated with food intake inhibition [80], correlating with its effect on foregut motility.

\section{RYamides}

RYamides are a group of neuropeptides very recently discovered and characterized in insects [65]. They are characterized by a C-terminal FFxxxRY-amide C-terminal sequence (Table 1). Their function, therefore, has yet to be elucidated, but expression of the RYamide receptors in the hindgut of $D$. melanogaster adult flies suggests a role of insect RYamides in digestion or water reabsorption [81]. In B. mori, RYamides are expressed in several neurons in the brain and terminal abdominal ganglion as well as in the EE cells of the anterior midgut of larvae, pupae and adults [82]. This expression pattern reinforces the previous suggestion of RYamides playing a role in the regulation of feeding and digestion. RYamide orthologs are found in most other insects with sequenced genomes, except for four sequenced ant genomes [83]. The ortholog for D. melanogaster, however, does not contain an exon encoding the signal peptide, suggesting that the gene is degenerating in this species [84]. RYamides have been described in other invertebrates, where they exert similar functions in feeding behaviour $[85,86]$.

\section{Trissin}

Another recently discovered peptide is trissin, first identified and characterized (Table 1) as a ligand of the D. melanogaster GPCR CG34381 [87]. Trissin-related neuropeptides and receptors of other insects have been predicted through sequence comparison with sequenced insect genomes and transcriptomes, among these are the orders of Homoptera, Neuroptera, Lepidoptera, Hymenoptera and Diptera [87, 88]. FlyAtlas [89]shows that trissin and its receptor are predominantly expressed in the brain and thoracico-abdominal ganglion in $D$. melanogaster. Through in situ hybridization, trissin expression was examined in B. mori, concluding that this neuropeptide's expression is restricted to only two pairs of small protocerebral interneurons and four to five large neurons in the frontal ganglion, which is a part of the SNS, innervating the alimentary canal [88]. In these neurons, trissin is coexpressed with several excitatory and inhibitory factors of gut musculature, such as AT, AST-A and myoinhibitory peptides [88]. 


\section{Conclusions}

Food intake stimulates the release of multiple neuropeptides from the central- or stomatogastric nervous systems and some are also released from the enteroendocrine cells in the gut. Our understanding of the neuropeptide regulation of feeding and digestion is still poor and fragmentary. Why have insects evolved to depend on several neuropeptides that perform similar functions? Gut motility is regulated by myostimulants (proctolin, allatotropin and kinins) and myoinhibitants (allatostatin, myosupressin and myoinhibitory peptides). It is also not well understood how the differential release and action of peptides, in some cases localized within the same neurons, is regulated.

Another interesting question concerns the interchangeable nature of some peptides. Insects have three allatostatins families and in many cases more than one family is present in the same species. Other peptides seem to be absent in some species (RYamides in the ant Acromyrmex echinatior) or in entire insect orders (proctolin in Lepidoptera).

The elucidation of the role of neuropeptides is further complicated by the observation of the species-dependent effects and the action of some peptides in a multitude of processes in gut physiology. Omics techniques and recent advances in technology are driving our understanding of these complex processes, while also aiding in the characterization of new insect neuropeptides that add to the complexity of gut physiology.

One fact that is clear is that a multitude of questions still need to be answered before we can begin to understand the full complexity of the intestinal processes in insects. However, since these neuropeptides are clearly one of the key factors in gut physiology, targeting their GPCRs to disrupt specific function(s) would be an interesting strategy for development of biorational pesticides. An interesting example are biostable kinin analogues, which have already been proposed as candidates for pest control.

\section{Acknowledgements}

The authors gratefully thank the Research Foundation of Flanders, FWO-FWF project (G0F2417N), as well as the LEAP-Agri consortium (LEAP-AGRI-360: 'Ento-economy' project) and FWO (G0I2118N, LEAP-AGRI co-fund JTC2017) for financial support of their research.

\section{Declaration of interests}

The authors declare no conflict of interest.

\section{References}

1. Nassel DR: Neuropeptides in the nervous system of Drosophila and other insects: multiple roles as neuromodulators and neurohormones. Prog Neurobiol 2002, 68:1-84.

2. Geary TG, Maule AG: Neuropeptide systems as targets for parasite and pest control. In Advances in Experimental Medicine and Biology. Landes Bioscience and Springer Science+Business Media, LLC; 2010

3. Caers J, Verlinden H, Zels S, Vandersmissen HP, Vuerinckx K, Schoofs L: More than two decades of research on insect neuropeptide GPCRs: an overview. Front Endocrinol (Lausanne) 2012, 3:151. 
4. Holtof M, Lenaerts C, Cullen D, Vanden Broeck J: Extracellular nutrient digestion and absorption in the insect gut. Cell Tissue Res 2019, 377:397-414.

5. Copenhaver PF: How to innervate a simple gut: familiar themes and unique aspects in the formation of the insect enteric nervous system. Dev Dyn 2007, 236:1841-64.

6. Kataoka H, Toschi A, Li JP, Carney RL, Schooley DA, Kramer SJ: Identification of an allatotropin from adult manduca sexta. Science 1989, 243:1481-3.

7. Woodhead AP, Stay B, Seidel SL, Khan MA, Tobe SS: Primary structure of four allatostatins: neuropeptide inhibitors of juvenile hormone synthesis. Proc Natl Acad Sci U S A 1989, 86:5997-6001.

8. Pratt GE, Farnsworth DE, Fok KF, Siegel NR, McCormack AL, Shabanowitz J, Hunt DF, Feyereisen R: Identity of a second type of allatostatin from cockroach brains: an octadecapeptide amide with a tyrosine-rich address sequence. Proc Natl Acad Sci U S A 1991, 88:2412-6.

9. Hillyer JF: Insect heart rhythmicity is modulated by evolutionarily conserved neuropeptides and neurotransmitters. Curr Opin Insect Sci 2018, 29:41-48.

10. Koladich PM, Tobe SS, McNeil JN: Enhanced haemolymph circulation by insect ventral nerve cord: hormonal control by Pseudaletia unipuncta allatotropin and serotonin. J Exp Biol 2002, 205:3123-31.

11. Chen J, Reiher W, Hermann-Luibl C, Sellami A, Cognigni P, Kondo S, Helfrich-Forster C, Veenstra JA, Wegener C: Allatostatin A Signalling in Drosophila Regulates Feeding and Sleep and Is Modulated by PDF. PLoS Genet 2016, 12:e1006346.

12. Petri B, Homberg U, Loesel R, Stengl M: Evidence for a role of GABA and Masallatotropin in photic entrainment of the circadian clock of the cockroach Leucophaea maderae. J Exp Biol 2002, 205:1459-69.

13. Verlinden H, Gijbels M, Lismont E, Lenaerts C, Vanden Broeck J, Marchal E: The pleiotropic allatoregulatory neuropeptides and their receptors: A mini-review. J Insect Physiol 2015, 80:2-14.

14. Aguilar R: Allatostatin gene expression in brain and midgut, and activity of synthetic allatostatins on feeding-related processes in the cockroach Blattella germanica. Regulatory Peptides 2003, 115:171-177.

15. Nakhaie Bahrami M, Mikani A, Moharramipour S: Effect of caffeic acid on feeding, alpha-amylase and protease activities and allatostatin-A content of Egyptian cotton leafworm, Spodoptera littoralis (Lepidoptera: Noctuidae). J Pestic Sci 2018, 43:73-78.

16. Bhatt TR, Horodyski FM: Expression of the Manduca sexta allatotropin gene in cells of the central and enteric nervous systems. J Comp Neurol 1999, 403:407-20.

17. Rankin SM, Kwok R, Seymour ML, Shaon Rahman U, Tobe SS: Effects of Manduca allatotropin and localization of Manduca allatotropin-immunoreactive cells in earwigs. Comp Biochem Physiol B Biochem Mol Biol 2005, 142:113-22.

18. Robertson L, Chasiotis H, Galperin V, Donini A: Allatostatin A-like immunoreactivity in the nervous system and gut of the larval midge Chironomus riparius: modulation of hindgut motility, rectal $K+$ transport and implications for exposure to salinity. J Exp Biol 2014, 217:3815-22.

19. Robertson L, Lange AB: Neural substrate and allatostatin-like innervation of the gut of Locusta migratoria. J Insect Physiol 2010, 56:893-901.

20. Duve $\mathrm{H}$, Thorpe A: Neuropeptide co-localisation in the lepidopteran frontal ganglion studied by confocal laser scanning microscopy. Cell Tissue Res 2003, 311:79-89. 
21. Duve H, East PD, Thorpe A: Regulation of lepidopteran foregut movement by allatostatins and allatotropin from the frontal ganglion. J Comp Neurol 1999, 413:40516.

22. Duve H, Audsley N, Weaver RJ, Thorpe A: Triple co-localisation of two types of allatostatin and an allatotropin in the frontal ganglion of the lepidopteran Lacanobia oleracea (Noctuidae): innervation and action on the foregut. Cell Tissue Res 2000, 300:153-63.

23. Robertson L, Rodriguez EP, Lange AB: The neural and peptidergic control of gut contraction in Locusta migratoria: the effect of an FGLa/AST. J Exp Biol 2012, 215:3394-402.

24. Vanderveken M, O'Donnell MJ: Effects of diuretic hormone 31, drosokinin, and allatostatin $A$ on transepithelial $\mathrm{K}(+)$ transport and contraction frequency in the midgut and hindgut of larval Drosophila melanogaster. Arch Insect Biochem Physiol 2014, 85:76-93.

25. Zandawala M, Orchard I: Post-feeding physiology in Rhodnius prolixus: the possible role of FGLamide-related allatostatins. Gen Comp Endocrinol 2013, 194:311-7.

26. Audsley N, Weaver RJ, Edwards JP: In vivo effects of Manduca sexta allatostatin and allatotropin on larvae of the tomato moth, Lacanobia oleracea. Physiological Entomology 2001, 26:181-188.

27. Matthews HJ, Down RE, Audsley N: Effects of Manduca sexta allatostatin and an analogue on the peach-potato aphid Myzus persicae (hemiptera: aphididae) and degradation by enzymes in the aphid gut. Arch Insect Biochem Physiol 2010, 75:13957.

28. Hergarden AC, Tayler TD, Anderson DJ: Allatostatin-A neurons inhibit feeding behavior in adult Drosophila. Proc Natl Acad Sci U S A 2012, 109:3967-72.

29. Duan Sahbaz B, Sezerman OU, Torun H, Birgul lyison N: Ligand binding pocket of a novel Allatostatin receptor type C of stick insect, Carausius morosus. Sci Rep 2017, 7:41266.

30. Huang SS, Chen SS, Zhang HL, Yang H, Yang HJ, Ren YJ, Kai ZP: Structure-Based Discovery of Nonpeptide Allatostatin Analogues for Pest Control. J Agric Food Chem 2018, 66:3644-3650.

31. Santini MS, Ronderos JR: Allatotropin-like peptide released by Malpighian tubules induces hindgut activity associated with diuresis in the Chagas disease vector Triatoma infestans (Klug). J Exp Biol 2007, 210:1986-91.

32. Santini MS, Ronderos JR: Allatotropin-like peptide in Malpighian tubules: insect renal tubules as an autonomous endocrine organ. Gen Comp Endocrinol 2009, 160:243-9.

33. Matthews HJ, Audsley N, Weaver RJ: In vitro and in vivo effects of myo-active peptides on larvae of the tomato moth Lacanobia oleracea and the cotton leaf worm Spodoptera littoralis (Lepidoptera; Noctuidae). Arch Insect Biochem Physiol 2008, 69:60-9.

34. Matsumoto S, Kutsuna N, Daubnerova I, Roller L, Zitnan D, Nagasawa H, Nagata S: Enteroendocrine peptides regulate feeding behavior via controlling intestinal contraction of the silkworm Bombyx mori. PLoS One 2019, 14:e0219050.

35. Oeh U, Dyker $\mathrm{H}$, Lösel $\mathrm{P}$, Hoffmann $\mathrm{KH}$ : In vivo effects of Manduca sexta allatotropin and allatostatin on development and reproduction in the fall armyworm,Spodoptera frugiperda(Lepidoptera, Noctuidae). Invertebrate Reproduction \& Development 2001, 39:239-247. 
36. Lwalaba D, Hoffmann $\mathrm{KH}$, Woodring J: Control of the release of digestive enzymes in the larvae of the fall armyworm, Spodoptera frugiperda. Arch Insect Biochem Physiol 2010, 73:14-29.

37. Holman GM, Cook BJ: Isolation and partial characterization of a second myotropic peptide from the hindgut of the cockroach, Leucophaea maderae. Comp Biochem Physiol C 1983, 76:p. 39-43.

38. Predel R, Kellner R, Rapus J, Penzlin H, Gade G: Isolation and structural elucidation of eight kinins from the retrocerebral complex of the American cockroach, Periplaneta americana. Regul Pept 1997, 71:199-205.

39. Te Brugge V, Paluzzi JP, Neupert S, Nachman RJ, Orchard I: Identification of kininrelated peptides in the disease vector, Rhodnius prolixus. Peptides 2011, 32:469-74.

40. Veenstra JA, Pattillo JM, Petzel DH: A single cDNA encodes all three Aedes leucokinins, which stimulate both fluid secretion by the malpighian tubules and hindgut contractions. J Biol Chem 1997, 272:10402-7.

41. Te Brugge VA, Nassel DR, Coast GM, Schooley DA, Orchard I: The distribution of a kininlike peptide and its co-localization with a CRF-like peptide in the blood-feeding bug, Rhodnius prolixus. Peptides 2001, 22:161-73.

42. Nachman RJ, Strey A, Isaac E, Pryor N, Lopez JD, Deng JG, Coast GM: Enhanced in vivo activity of peptidase-resistant analogs of the insect kinin neuropeptide family. Peptides 2002, 23:735-45.

43. Nachman RJ, Coast GM, Douat C, Fehrentz JA, Kaczmarek K, Zabrocki J, Pryor NW, Martinez J: A C-terminal aldehyde insect kinin analog enhances inhibition of weight gain and induces significant mortality in Helicoverpa zea larvae. Peptides 2003, 24:1615-21.

44. Lange AB, Nachman RJ, Kaczmarek K, Zabrocki J: Biostable insect kinin analogs reduce blood meal and disrupt ecdysis in the blood-gorging Chagas' disease vector, Rhodnius prolixus. Peptides 2016, 80:108-113.

45. Sangha V, Nachman RJ, Lange A, Orchard I: Physiological effects of biostable kinin and CAPA analogs in the Chagas disease vector, Rhodnius prolixus. Insect Biochem Mol Biol 2019, 114:103223.

46. Smagghe G, Mahdian K, Zubrzak P, Nachman RJ: Antifeedant activity and high mortality in the pea aphid Acyrthosiphon pisum (Hemiptera: Aphidae) induced by biostable insect kinin analogs. Peptides 2010, 31:498-505.

47. Gade G: Regulation of intermediary metabolism and water balance of insects by neuropeptides. Annu Rev Entomol 2004, 49:93-113.

48. Keeley LL, Chung JS, Hayes TK: Diuretic and antifeedant actions by Manduca sexta diuretic hormone in lepidopteran larvae. Experientia 1992, 48:1145-1148.

49. Audsley N, Goldsworthy GJ, Coast GM: Circulating levels of Locusta diuretic hormone: the effects of feeding. Peptides 1997, 18:59-65.

50. Audsley N, Goldsworthy GJ, Coast GM: Quantification of Locusta diuretic hormone in the central nervous system and corpora cardiaca: influence of age and feeding status, and mechanism of release. Regul Pept 1997, 69:25-32.

51. Goldsworthy GJ, Chung JS, Simmonds MS, Tatari M, Varouni S, Poulos CP: The synthesis of an analogue of the locust CRF-like diuretic peptide, and the biological activities of this and some C-terminal fragments. Peptides 2003, 24:1607-13. 
52. Van Wielendaele P, Dillen S, Marchal E, Badisco L, Vanden Broeck J: CRF-like diuretic hormone negatively affects both feeding and reproduction in the desert locust, Schistocerca gregaria. PLoS One 2012, 7:e31425.

53. Mollayeva S, Orchard I, Lange AB: The involvement of Rhopr-CRF/DH in feeding and reproduction in the blood-gorging insect Rhodnius prolixus. Gen Comp Endocrinol 2018, 258:79-90.

54. Lee HR, Zandawala $\mathrm{M}$, Lange $\mathrm{AB}$, Orchard I: Isolation and characterization of the corticotropin-releasing factor-related diuretic hormone receptor in Rhodnius prolixus. Cell Signal 2016, 28:1152-62.

55. Urbanski A, Lubawy J, Marciniak P, Rosinski G: Myotropic activity and immunolocalization of selected neuropeptides of the burying beetle Nicrophorus vespilloides (Coleoptera: Silphidae). Insect Sci 2019, 26:656-670.

56. Bhatt G, da Silva R, Nachman RJ, Orchard I: The molecular characterization of the kinin transcript and the physiological effects of kinins in the blood-gorging insect, Rhodnius prolixus. Peptides 2014, 53:148-58.

57. Lange $\mathrm{AB}: \mathrm{A}$ review of the involvement of proctolin as a cotransmitter and local neurohormone in the oviduct of the locust, Locusta migratoria. Peptides 2002, 23:2063-70.

58. Vezenkov SR, Danalev DL: From molecule to sexual behavior: the role of the neuropentapeptide proctolin in acoustic communication in the male grasshopper Chorthippus biguttulus. Eur J Pharmacol 2009, 619:57-60.

59. Hertel W, Neupert S, Eckert M: Proctolin in the antennal circulatory system of lower Neoptera: a comparative pharmacological and immunohistochemical study. Physiological Entomology 2012, 37:160-170.

60. Starratt AN, Brown BE: Structure of the pentapeptide proctolin, a proposed neurotransmitter in insects. Life Sci 1975, 17:1253-6.

61. Brown BE: Proctolin: a peptide transmitter candidate in insects. Life Sci 1975, 17:124152.

62. Koziol U: Precursors of neuropeptides and peptide hormones in the genomes of tardigrades. Gen Comp Endocrinol 2018, 267:116-127.

63. Veenstra JA: Neurohormones and neuropeptides encoded by the genome of Lottia gigantea, with reference to other mollusks and insects. Gen Comp Endocrinol 2010, 167:86-103.

64. Christie AE, Pascual MG, Yu A: Peptidergic signaling in the tadpole shrimp Triops newberryi: A potential model for investigating the roles played by peptide paracrines/hormones in adaptation to environmental change. Mar Genomics 2018, 39:45-63.

65. Hauser F, Neupert S, Williamson M, Predel R, Tanaka Y, Grimmelikhuijzen CJ: Genomics and peptidomics of neuropeptides and protein hormones present in the parasitic wasp Nasonia vitripennis. J Proteome Res 2010, 9:5296-310.

66. Predel R, Neupert S, Garczynski SF, Crim JW, Brown MR, Russell WK, Kahnt J, Russell DH, Nachman RJ: Neuropeptidomics of the mosquito Aedes aegypti. J Proteome Res 2010, 9:2006-15.

67. Xu G, Gu GX, Teng ZW, Wu SF, Huang J, Song QS, Ye GY, Fang Q: Identification and expression profiles of neuropeptides and their $G$ protein-coupled receptors in the rice stem borer Chilo suppressalis. Sci Rep 2016, 6:28976. 
68. Roller L, Yamanaka N, Watanabe K, Daubnerova I, Zitnan D, Kataoka H, Tanaka Y: The unique evolution of neuropeptide genes in the silkworm Bombyx mori. Insect Biochem Mol Biol 2008, 38:1147-57.

69. Fiandra L, Casartelli M, Diamante B, Giordana B: Proctolin affects gut functions in lepidopteran larvae. Journal of Applied Entomology 2010, 134:745-753.

70. Howarth CJ, Prince RI, Dyker H, Losel PM, Seinsche A, Osborne RH: Structure-activity relationship of contractile effects induced by helicokinins in the isolated gut of the lepidopteran caterpillar Spodoptera frugiperda. J Insect Physiol 2002, 48:75-82.

71. Dircksen H, Neupert S, Predel R, Verleyen P, Huybrechts J, Strauss J, Hauser F, Stafflinger E, Schneider M, Pauwels K, Schoofs L, Grimmelikhuijzen CJ: Genomics, transcriptomics, and peptidomics of Daphnia pulex neuropeptides and protein hormones. J Proteome Res 2011, 10:4478-504.

72. Spittaels K, Vankeerberghen A, Torrekens S, Devreese B, Grauwels L, Van Leuven F, Hunt D, Shabanowitz J, Schoofs L, Van Beeumen J, et al.: Isolation of Ala1-proctolin, the first natural analogue of proctolin, from the brain of the Colorado potato beetle. Mol Cell Endocrinol 1995, 110:119-24.

73. Clark L, Agricola HJ, Lange AB: Proctolin-like immunoreactivity in the central and peripheral nervous systems of the locust, Locusta migratoria. Peptides 2006, 27:54958.

74. Cantera R, Nassel DR: Dual peptidergic innervation of the blowfly hindgut: a light- and electron microscopic study of FMRFamide and proctolin immunoreactive fibers. Comp Biochem Physiol C 1991, 99:517-25.

75. Wood SJ, Osborne RH, Banner SE, Cattell KJ: Effects of FMRFamide-related peptides and morphine on the isolated foregut of the locust Schistocerca gregaria. Comp Biochem Physiol C 1992, 103:315-20.

76. Banner SE, Wood SJ, Osborne RH, Cattell KJ: Tyramine antagonizes proctolin-induced contraction of the isolated foregut of the locust Schistocerca gregaria by an interaction with octopamine2 receptors. Comp Biochem Physiol C 1990, 95:233-6.

77. Lange $A B$, Orchard I: The effects of SchistoFLRFamide on contractions of locust midgut. Peptides 1998, 19:459-67.

78. Orchard I, Lee DH, da Silva R, Lange AB: The Proctolin Gene and Biological Effects of Proctolin in the Blood-Feeding Bug, Rhodnius prolixus. Front Endocrinol (Lausanne) 2011, 2:59.

79. Cook BJ, Holman GM: The role of proctolin and glutamate in the excitation-contraction coupling of insect visceral muscle. Comp Biochem Physiol C 1985, 80:65-73.

80. Maestro JL, Aguilar R, Pascual N, Valero ML, Piulachs MD, Andreu D, Navarro I, Belles $\mathrm{X}$ : Screening of antifeedant activity in brain extracts led to the identification of sulfakinin as a satiety promoter in the German cockroach. Are arthropod sulfakinins homologous to vertebrate gastrins-cholecystokinins? Eur J Biochem 2001, 268:582430.

81. Collin C, Hauser F, Krogh-Meyer P, Hansen KK, Gonzalez de Valdivia E, Williamson M, Grimmelikhuijzen $\mathrm{CJ}$ : Identification of the Drosophila and Tribolium receptors for the recently discovered insect RYamide neuropeptides. Biochem Biophys Res Commun 2011, 412:578-83.

82. Roller L, Cizmar D, Bednar B, Zitnan D: Expression of RYamide in the nervous and endocrine system of Bombyx mori. Peptides 2016, 80:72-79. 
83. Nygaard S, Zhang G, Schiott M, Li C, Wurm Y, Hu H, Zhou J, Ji L, Qiu F, Rasmussen M et al.: The genome of the leaf-cutting ant Acromyrmex echinatior suggests key adaptations to advanced social life and fungus farming. Genome Res 2011, 21:133948.

84. Veenstra JA, Khammassi H: Rudimentary expression of RYamide in Drosophila melanogaster relative to other Drosophila species points to a functional decline of this neuropeptide gene. Insect Biochem Mol Biol 2017, 83:68-79.

85. Chen R, Hui L, Cape SS, Wang J, Li L: Comparative Neuropeptidomic Analysis of Food Intake via a Multi-faceted Mass Spectrometric Approach. ACS Chem Neurosci 2010, 1:204-214.

86. Proekt A, Vilim FS, Alexeeva V, Brezina V, Friedman A, Jing J, Li L, Zhurov Y, Sweedler JV, Weiss KR: Identification of a new neuropeptide precursor reveals a novel source of extrinsic modulation in the feeding system of Aplysia. J Neurosci 2005, 25:9637-48.

87. Ida T, Takahashi T, Tominaga H, Sato T, Kume K, Yoshizawa-Kumagaye K, Nishio H, Kato J, Murakami N, Miyazato $\mathrm{M}$ et al.: Identification of the endogenous cysteine-rich peptide trissin, a ligand for an orphan $G$ protein-coupled receptor in Drosophila. Biochem Biophys Res Commun 2011, 414:44-8.

88. Roller L, Cizmar D, Galikova Z, Bednar B, Daubnerova I, Zitnan D: Molecular cloning, expression and identification of the promoter regulatory region for the neuropeptide trissin in the nervous system of the silkmoth Bombyx mori. Cell Tissue Res 2016, 364:499-512.

89. Chintapalli VR, Wang J, Dow JA: Using FlyAtlas to identify better Drosophila melanogaster models of human disease. Nat Genet 2007, 39:715-20.

90. Weaver RJ, Freeman ZA, Pickering MG, Edwards JP: Identification of two allatostatins from the CNS of the cockroach Periplaneta americana: Novel members of a family of neuropeptide inhibitors of insect juvenile hormone biosynthesis. Comp Biochem Physiol C 1994, 107:119-127.

91. Lorenz MW, Kellner R, Hoffmann $\mathrm{KH}$ : A family of neuropeptides that inhibit juvenile hormone biosynthesis in the cricket, Gryllus bimaculatus. I Biol Chem 1995, 270:21103-8.

92. Kramer SJ, Toschi A, Miller CA, Kataoka H, Quistad GB, Li JP, Carney RL, Schooley DA: Identification of an allatostatin from the tobacco hornworm Manduca sexta. Proc Natl Acad Sci U S A 1991, 88:9458-9462.

93. Abdel-latief $\mathrm{M}$, Meyering-Vos $\mathrm{M}$, Hoffmann $\mathrm{KH}$ : Molecular characterisation of cDNAs from the fall armyworm Spodoptera frugiperda encoding Manduca sexta allatotropin and allatostatin preprohormone peptides. Insect Biochem Mol Biol 2003, 33:467-76

94. Abdel-latief $\mathrm{M}$, Meyering-Vos $\mathrm{M}$, Hoffmann $\mathrm{KH}$ : Characterization of a novel peptide with allatotropic activity in the fall armyworm Spodoptera frugiperda. Regul Pept 2004, 122:69-78

95. Kataoka H, Troetschler RG, Li JP, Kramer SJ, Carney RL, Schooley DA: Isolation and identification of a diuretic hormone from the tobacco hornworm, Manduca sexta. Proc Natl Acad Sci U S A 1989, 86:2976-80 
Table 1: The structure of neuropeptides with the insect species from which they were isolated. The consensus sequence is indicated in bold.

\begin{tabular}{|c|c|c|c|}
\hline Peptide group & Sequence & Insect species & References \\
\hline Allatostatin-A & SPSGMQRLYGFGL-amide & Periplaneta americana & {$[90]$} \\
\hline Allatostatin-B & GWQDLNGGW-amide & Gryllus bimaculatus & [91] \\
\hline Allatostatin-C & pEVRFRQCYFNPISCF & Manduca sexta & [92] \\
\hline Allatotropin & GFKNVEMMTARGF-amide & $\begin{array}{l}\text { Manduca sexta, } \\
\text { Spodoptera frugiperda }\end{array}$ & {$[6],[93]$} \\
\hline Allatotropin-2 & RVRGNPISCF & Spodoptera frugiperda & [94] \\
\hline Kinins & RPSFNSWG-amide & Periplaneta americana & {$[38]$} \\
\hline $\mathrm{CRF} / \mathrm{DH}$ & $\begin{array}{l}\text { RMPSLSIDLPMSVLRQKLSLEKERKVHALRAAA } \\
\text { NRNFLNDI-amide }\end{array}$ & Manduca sexta & {$[95]$} \\
\hline Proctolin & RYLPT & Periplaneta americana & {$[60]$} \\
\hline Ala $^{1}$-proctolin & AYLPT & Leptinotarsa decemlineata & {$[72]$} \\
\hline RYamide & SEDRSSGNSLKESSFFSPGRY-amide & Nasonia vitripennis & {$[65]$} \\
\hline Trissin & IKCDTCGKECASACGTKHFRTCCFNYL & Drosophila melanogaster & [87] \\
\hline
\end{tabular}


Figure 1: A generalized schematic overview of the insect gastrointestinal tract, with the neuropeptides acting on each gut section.

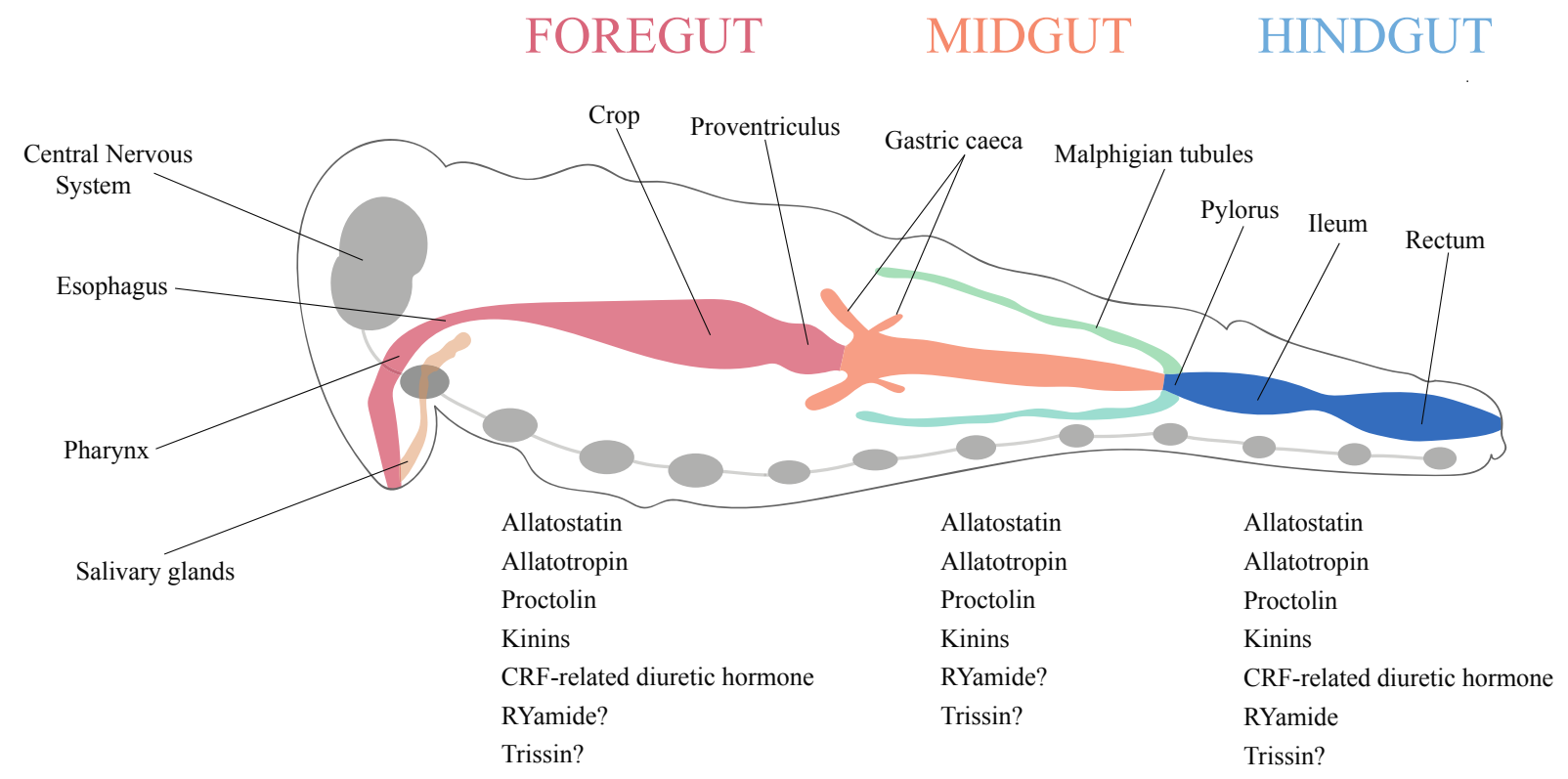


Figure 2: A generalized schematic overview of the insect enteric nervous system (ENS) and the site of production (in cases where this is known) of each neuropeptide within the ENS. The frontal ganglion, hypocerebral ganglion and ventricular ganglion are components of the SNS. The abdominal ganglion lies in the ventral nerve cord and is part of the central nervous system (CNS). The frontal ganglion connects to the brain by the frontal ganglion connective, while the recurrent nerve links it to the hypocerebral ganglion. The hypocerebral ganglion is in turn connected to the corpora cardiaca and the ventricular ganglion via the esophageal nerve. These ganglia also give rise to diffuse nerve plexuses that innervate the foregut musculature. From the ventricular ganglion, a branching nerve plexus (the midgut enteric plexus) extends along the superficial musculature of the midgut. The hindgut is innervated by branches of the proctodeal and rectal nerves that extend from the terminal abdominal ganglion; branches of the proctodeal nerve also extend onto the posterior midgut.

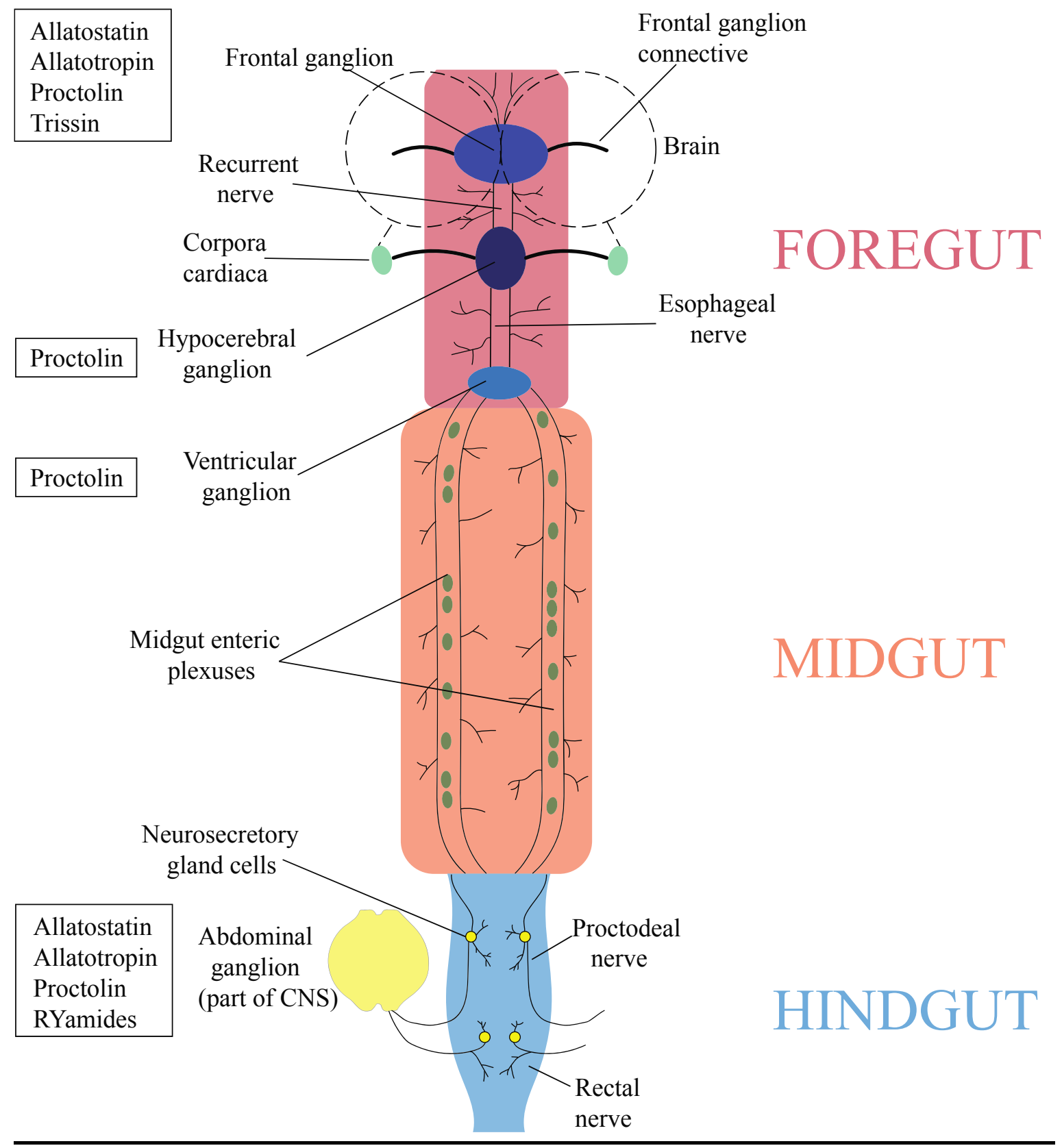


**Duan Sahbaz, B., et al., Ligand binding pocket of a novel Allatostatin receptor type C of stick insect, Carausius morosus. Sci Rep, 2017. 7: p. 41266.

This paper reports on the structural study of allatostatins $\mathrm{C}$ with its receptor in Carausius morosus to identify the allatostatin $\mathrm{C}$ binding pocket. The study uses a combination of molecular docking onto the 3D structure of the receptor and in silico analysis to predict the binding motif in the allatostatin receptor as well as atomic force microscopy and site-directed mutagenesis to measure the physical interaction between allatostatin and different mutated versions of the receptor. This can have important implications for design of neuropeptide analogues for pest control.

*Huang, S.S., et al., Structure-Based Discovery of Nonpeptide Allatostatin Analogues for Pest Control. J Agric Food Chem, 2018. 66(14): p. 3644-3650.

This paper reports on the use of molecular docking of FGL-amide allatostatin (AST-A) in the Diploptera punctata allatostatin receptor and structure-activity relationship to design nonpeptide allatostatin analogues, of which two had a significant larvicidal effect, when administered orally. These compounds can be considered as potential insecticidal agents.

** Chen, J., et al., Allatostatin A Signalling in Drosophila Regulates Feeding and Sleep and Is Modulated by PDF. PLoS Genet, 2016. 12(9): p. e1006346.

Using transgenic flies with a temperature controlled thermogenic activator for allatostatin-A expression, the group of Wegener demonstrate the effect of AST-A neuron/cell expression on feeding and the subset of neurons/cells essential for suppression of feeding.

*Mollayeva, S., I. Orchard, and A.B. Lange, The involvement of Rhopr-CRF/DH in feeding and reproduction in the blood-gorging insect Rhodnius prolixus. Gen Comp Endocrinol, 2018. 258: p. 79-90.

This paper reported on CRF/DH in Rhodnius prolixus, a blood gorging insect and vector for human Chagas disease. The study highlights targets to alter both feeding, diuresis and reproduction for this disease vector. 
** Holtof M, Lenaerts C, Cullen D, Vanden Broeck J: Extracellular nutrient digestion and absorption in the insect gut. Cell Tissue Res 2019, 377:397-414

This extensive review discusses the anatomy of the insect gut with a focus on the insect midgut and how macronutrients (proteins, carbohydrates and lipids) are digested and absorbed in the highly specialized compartments of the insect gut.

* Veenstra JA, Khammassi H. 2017. Rudimentary expression of RYamide in Drosophila melanogaster relative to other Drosophila species points to a functional decline of this neuropeptide gene. Insect Biochem Mol Biol 83:68-79

This paper reported on the $D$. melanogaster RYamide gene. They suggest that the RYamide Drome-gene is evolving into a pseudogene, since an exon encoding a signal peptide is absent, in contrast to other Drosphila and insect species. When expression of the neuropeptide was studied in several Drosophila species using specific antisera, it was found that the DromeRYamide is only expressed in two neurons, in contrast to other Drosophila species, where it is expressed in numerous neurons and enteroendocrine cells. 